\title{
Synthesis of 2-Arylbenzothiazoles Catalyzed by Biomimetic Catalyst, $\beta$-Cyclodextrin
}

\author{
Balaji S. Londhe, Umesh R. Pratap, Jyotirling R. Mali, and Ramrao A. Mane* \\ Department of Chemistry, Dr. Babasaheb Ambedkar Marathwada University, Aurangabad (M.S.) 431004 India \\ *E-mail:manera@indiatimes.com \\ Received May 12, 2010, Accepted June 29, 2010
}

\begin{abstract}
Cyclocondensation of 2-aminothiophenol and aryl/heteryl aldehydes has been carried using biomimetic catalyst, $\beta$ Cyclodextrin in water and obtained 2-aryl/heteryl benzothiazoles with better to excellent yields. This biomimetic catalyzed route is simple, economic, and environmentally benign.
\end{abstract}

Key Words: 2-Arylbenzothiazole, Water chemistry, $\beta$-Cyclodextrin, Cyclocondensation

\section{Introduction}

The exploration of privileged structures in drug discovery is rapidly emerging theme in medicinal chemistry. Benzothiazole and its derivatives belong to such immensely important class of heterocyclic systems, owing to their potent antitumor activity $^{1}$ and other important pharmaceutical utilities. ${ }^{2}$ Their significance is also due to their applications in the treatment of autoimmune, inflammatory, epilepsy, analgesia, viral, cancer, tuberculosis diseases, and the prevention of organ transplant rejection. ${ }^{3-9}$ Also, they have been widely used in industry as antioxidants and vulcanization accelerators that highlight their synthetic necessity. ${ }^{10}$

Numerous methods have been reported in the literature for the synthesis of benzothiazoles. Traditionally used methods are (i) condensation of 2-aminothiophenols with aldehydes, ${ }^{11}$ carboxylic acids, ${ }^{12}$ acid chlorides, ${ }^{13}$ or esters ${ }^{14}$ and (ii) Jacobson's cyclization of thiobenzanilides. ${ }^{15}$ Unfortunately, many of these existing methods, used for the synthesis of benzothiazoles accompanying with one or other kinds of the disadvantages, such as, use of volatile organic solvents, costly air sensitive reagents, ${ }^{11 a}$ prolonged reaction time,${ }^{16}$ multistep reaction sequences, ${ }^{15}$ high reaction temperature, ${ }^{11 \mathrm{e}}$ requirement of extreme $\mathrm{pH},{ }^{15 \mathrm{~d}, 15 \mathrm{e}}$ tedious work-up procedures, ${ }^{11 \mathrm{e}}$ and generation of solid wastes. ${ }^{17}$ Therefore, more attention has been directed to overcome the above limitations by providing an efficient and convenient protocol for the synthesis of 2 -substituted benzothiazoles. $^{17}$

Recently, more efforts have been put on the use of biocatalysts i.e. functional enzymes as excellent catalysts ${ }^{18}$ to accelerate organic transformations because of their specificity and selectivity. Enzymes catalyze organic transformations at ambient temperature, atmospheric pressure and in an aqueous medium. These advantageous and distinguishing features of the enzymes have been utilized to carry out variety of organic transformations leading to bioactive molecules. There are number of reports appeared in the literature on enzymatic catalysis in organic synthesis. ${ }^{18}$ However, it is not always preferable to use the enzymes as a catalysts in the synthetic protocols, mainly due to their high cost, ${ }^{19}$ waste management problems, ${ }^{17}$ less availability of pure enzymes, narrow substrate specificity and requirement of complicated co-substrates such as co-factors. ${ }^{20}$ Recently, we have reported the use of whole cell biocatalyst ${ }^{17}$ in the synthesis of benzothiazoles. There it was noticed that the route has been found to give good yields of the benzothiazoles after prolonged reaction time. However it requires huge amount of baker's yeast as a catalyst. Therefore, this route has also problem of solid waste disposal and non-recyclibility of the biocatalyst.

To overcome these limitations and to retain the advantages of biocatalysts, readily available biomimetic catalysts are gaining importance because of their selectivity, like enzymes and can be used at mild reaction conditions to run the chemical transformations leading to biodynamic molecules. ${ }^{21}$

While revealing the literature it was observed that $\beta$-cyclodextrin, a biomimetic catalyst ${ }^{22}$ has been recently employed for carrying wide spectrum of organic transformations ${ }^{21}$ such as, synthesis of thiazoles, synthesis of $\beta$-hydroxy sulfides from alkenes, hydrolysis of oxiranes, deprotection of aromatic acetals, synthesis of selenazoles, Strecker reaction in water, regeoselective ring opening of oxiranes with phenoxides, synthesis of quinoxalines in water etc. Recently Bhosale et. al. have published a review which gives emphasis on the use of $\beta$-cyclodextrin as a catalyst in organic syntheses. ${ }^{23}$ It was also revealed that, $\beta$-cyclodextrin does not find use in the cyclocondensation of aryl/heteryl aldehydes and 2-amino thiophenol leading to 2 -aryl/heteryl benzothiazoles.

$\beta$-Cyclodextrin ( $\beta$-CD) is cyclic oligosaccharide containing inner hydrophobic cavity. It exerts micro-environmental effects on the reactant molecules which lead to selective reactions. Reactions catalyzed by them involve supramolecular catalysis due to non-covalent bonding forming reversible complexes between substrates and $\beta$-cyclodextrin as seen in the enzymes. ${ }^{24}$ These biomimetic reactions can be effectively carried out in water at neutral $\mathrm{pH}$ without generating any toxic waste products; thus, exactly mimicking biocatalytic conditions. Owing to these facts cyclodextrins are perfectly considered as enzyme models and reactions under supramolecular catalysis will be superior to chemical catalysis.

Inspired by these attractive features of cyclodextrin as a biomimic i.e., biomimetic catalyst and as a part of our drive towards the syntheses of bioactive molecules accelerated by biocataly$\mathrm{sts}^{17} /$ biomimetic catalysts, and to remove the hurdles in the traditional routes of benzothiazoles, here we report for the first time biomimetic route for the synthesis of 2-substituted ben- 
Table 1. Optimization for appropriate catalyst

\begin{tabular}{ccccc}
\hline Entry & Catalyst & $\begin{array}{c}\text { Reaction Temp. } \\
\left({ }^{\circ} \mathrm{C}\right)\end{array}$ & $\begin{array}{c}\text { Time } \\
(\text { hr. })\end{array}$ & $\begin{array}{c}\text { Yields }^{a} \\
(\%)\end{array}$ \\
\hline 1 & aq. CTAB & 50 & 9.5 & 52 \\
2 & aq. SDS & 50 & 10 & Trace \\
3 & aq. $\beta$-CD & 50 & 1.5 & 92 \\
\hline
\end{tabular}

${ }^{a}$ Isolated yields

$$
{ }_{2 \text { a-n }}^{\mathrm{SH}}+\underset{\mathrm{H}_{2} \mathrm{O}, 50^{\circ} \mathrm{C}}{\mathrm{R}-\mathrm{CHO}} \underset{\text { 3a-n }}{\stackrel{\beta-c y c l o d e x t r i n}{\longrightarrow}}
$$

Scheme 1

zothiazoles by carrying the cyclocondensation of 2-aminothiophenol and aryl/heteryl aldehydes in aqueous $\beta$-cyclodextrin.

\section{Results and Discussion}

Considering the need of safer medium like water and importance of biomimetic supramolecular catalysts, we attempted the cyclocondensations of aryl aldehydes and 2-amino thiophenol separately in cationic surfactants (CTAB), anionic surfactant (SDS) and non-ionic biomimetic catalyst ( $\beta$-cyclodextrin). It was observed that the condensation successfully led to benzothiazoles, when carried in aqueous $\beta$-cyclodextrin at $50{ }^{\circ} \mathrm{C}$ (Table 1$)$.

Encouraged by these observations we tried to optimize the reaction conditions to obtain better to excellent yields of the benzothiazoles using aqueous solution of $\beta$-cyclodextrin as a catalyst and medium. The condensation has been carried by varying amount of $\beta$-cyclodextrin and reaction temperature. It was noticed that better yields of the benzothiazoles were obtained when equimolar quantities of the alcoholic concentrated solutions of aldehydes and 2-aminothiophenol were stirred in equimolar aqueous $(5.6 \%)$ solution of $\beta$-cyclodextrin at $50{ }^{\circ} \mathrm{C}$.

Here, rate enhancement of the cyclocondensations has been noted. The time required for the completion compared to the condensation carried by baker's yeast ${ }^{17}$ has been found to be markly reduced from 24 hours to 2 to 3 hours. This protocol is superior as compared to biocatalyst catalyzed cyclocondensation as it is not accompanying with solid waste and is relatively rapid and simple.

The rate acceleration of this condensation can be attributed to (1) aqueous $\beta$-cyclodextrin provides a unique hydrophobic truncated cone shaped cavity and hydrophilic outwardly hydroxyl groups. The aldehydes might be forming non covalent reversible supramolecular complexes with $\beta$-cyclodextrin in the cavity, enhancing the localized concentration of the aldehydes resulting in the dissolution of aldehydes in aqueous medium. Because of this aldehydes become readily available to interact with 2-aminothiophenol and (2) the electrophilic behavior of carbonyl carbon of the aldehydes would have been enhanced because of intermolecular hydrogen bonding between outwardly hydroxyl groups of $\beta$-cyclodextrin and carbonyl oxygen of the aldehydes. The enhancement in the localized concentra- tion of aldehydes and electrophilic behavior of carbonyl carbon would be responsible to accelerate the condensation rate compared to the condensation carried by biocatalyst.

To generalize this biomimetic synthetic route (Scheme 1) for the synthesis of 2-substituted benzothiazoles, we have tried the reactions for a series of aromatic as well as hetero-aromatic aldehydes and 2-aminothiophenol for getting known as well as new benzothiazoles. As expected all the reactions proceeded smoothly to afford the desired products with good to excellent yields (Table 2).

\begin{tabular}{|c|c|c|c|c|c|}
\hline Entry & $\mathrm{R}$ & $\begin{array}{l}\text { Time } \\
(\mathrm{min})\end{array}$ & $\begin{array}{l}\text { Yield } \\
(\%)^{b}\end{array}$ & $\operatorname{mp}\left({ }^{\circ} \mathrm{C}\right)$ & Reference \\
\hline $3 \mathbf{a}$ & & 75 & 92 & $112-113$ & $11 d$ \\
\hline $3 b$ & & 70 & 90 & $119-120$ & $11 d$ \\
\hline $3 c$ & & 65 & 78 & $173-174$ & $11 \mathrm{c}$ \\
\hline 3d & & 65 & 81 & $85-86$ & $11 \mathrm{~d}$ \\
\hline $3 e$ & & 50 & 86 & $228-229$ & $11 d$ \\
\hline $3 f$ & & 85 & 85 & $114-115$ & $11 \mathrm{~d}$ \\
\hline $3 g$ & & 120 & 70 & $230-231$ & $11 \mathrm{c}$ \\
\hline $3 \mathrm{~h}$ & & 95 & 88 & $131-132$ & $11 \mathrm{~d}$ \\
\hline $3 \mathbf{i}$ & & 115 & 83 & $101-102$ & $11 \mathrm{~d}$ \\
\hline $3 \mathbf{j}$ & & 140 & 76 & $102-103$ & $11 d$ \\
\hline $3 k$ & & 155 & 84 & $99-100$ & $11 \mathrm{c}$ \\
\hline $31^{c}$ & & 185 & 81 & $129-130$ & - \\
\hline $3 m^{c}$ & & 180 & 80 & $159-160$ & - \\
\hline $3 n^{c}$ & & 190 & 77 & $178-179$ & - \\
\hline
\end{tabular}

Table 2. 2-Arylbenzothiazoles ${ }^{a}$ (3a-n)

${ }^{a}$ The products were characterized by comparison of their spectroscopic (IR, ${ }^{\mathrm{P}} \mathrm{H}$ NMR, and Mass) and physical data with those reported in the literature. ${ }^{b}$ Isolated yields. ${ }^{c}$ New products. 


\section{Conclusion}

We have first time successfully applied the biomimetic approach for the synthesis of 2-substituted benzothiazoles by carrying the cyclocondensation of 2-aminothiophenol and aryl/heteryl aldehydes in water at neutral $\mathrm{pH}$ using $\beta$-cyclodextrin as a biomimetic catalyst. This biomimetic synthetic protocol has many advantages. It can be carried at lower temperature, neutral $\mathrm{pH}$, atmospheric pressure, in absence of acidic/metallic catalyst etc. The biomimetic catalyst used i.e. $\beta$-cyclodextrin is cheaper, readily available and can be recycled and reused.

\section{Experimental}

Chemicals required for the synthesis were obtained from $\mathrm{S}$. D. Fine Chemicals. $\beta$-Cyclodextrin used was of HiMedia Laboratories. Melting points were taken in open capillary tubes and are uncorrected. IR spectra were recorded on JASCO FT-IR 4100, Japan Spectrophotometer using $\mathrm{KBr}$ discs. ${ }^{1} \mathrm{H}$ NMR spectra were recorded with a Bruker DRX at $300 \mathrm{MHz}$, and 200 $\mathrm{MHz}$ in $\mathrm{CDCl}_{3}$ and DMSO- $d_{6}$ with TMS as an internal standard. Mass spectra were obtained from Joel AccuTOF DART Mass Spectrometers.

General experimental procedure for the synthesis of 2-arylbenzothiazoles. $\beta$-Cyclodextrin $(1 \mathrm{mmol})$ was dissolved in water $(20 \mathrm{~mL})$ with stirring at $50^{\circ} \mathrm{C}$. To this clear solution alcoholic solution of aryl aldehydes ( $1 \mathrm{mmol}$ in $2 \mathrm{~mL}$ ethanol) was added dropwise. To this then dropwise alcoholic solution of 2-aminothiophenol ( $1 \mathrm{mmol}$ in $2 \mathrm{~mL}$ ethanol) was added. Then the reaction mass was stirred at $50{ }^{\circ} \mathrm{C}$ till the completion of the reaction (as confirmed by Thin Layer Chromatography). After completion of the reaction, the reaction mixture was extracted with ethyl acetate $(2 \times 10 \mathrm{~mL})$. The organic layer was washed with water, saturated brine solution and dried over anhydrous sodium sulphate. The combined organic layer was evaporated under reduced pressure and thus obtained crude product was further purified by column chromatography with ethyl acetate: hexane $(2: 8)$ as an eluent. The aqueous layer was then cooled to $0{ }^{\circ} \mathrm{C}$; in which $\beta$-cyclodextrin reappeared as white solid. Thus obtained white solid mass then filtered and washed with water to recover $\beta$-cyclodextrin.

It was noticed that, the cyclocondensation has been found to be completed within 2 to $3 \mathrm{hr}$, resulting in better to excellent yields of the benzothiazoles (3a-n).

Spectral data for selected compounds.

Compound 3b: ${ }^{1} \mathrm{H}$ NMR (400 MHz, DMSO- $d_{6}$ ) $\delta 3.85$ (s, $3 \mathrm{H}), 7.1(\mathrm{~d}, J=8.8 \mathrm{~Hz}, 2 \mathrm{H}), 7.4(\mathrm{t}, J=7.6 \mathrm{~Hz}, 1 \mathrm{H}), 7.5(\mathrm{t}, J=$ $8 \mathrm{~Hz}, 1 \mathrm{H}), 8.0(\mathrm{~d}, 1 \mathrm{H}), 8.05(\mathrm{~d}, J=8.2,2 \mathrm{H}), 8.1(\mathrm{~d}, J=7.6 \mathrm{~Hz}$, $1 \mathrm{H}) . \mathrm{ES}^{+} \mathrm{MS} m / z=242.1\left(\mathrm{M}^{+}\right)$. IR: (KBr disc) $\mathrm{cm}^{-1}: 1618$ (aromatic ring); $1592(\mathrm{C}=\mathrm{N})$.

Compound 3I: ${ }^{1} \mathrm{H}$ NMR $\left(300 \mathrm{MHz}, \mathrm{CDCl}_{3}\right) \delta$ 7.31-7.38 (dd, $J=8 \& 6 \mathrm{~Hz}, 2 \mathrm{H}), 7.45-7.60$ (m, 5H, Ar-H), 7.74-7.85 (m, $5 \mathrm{H}, \mathrm{Ar}-\mathrm{H}), 8.03$ (d, $J=6 \mathrm{~Hz}, 2 \mathrm{H}), 8.7$ (s, 1H, pyrazolyl-H). $\mathrm{ES}^{+} \mathrm{MS} m / z 354.15\left(\mathrm{M}^{+}\right)$. IR ( $\mathrm{KBr}$ disc) $\mathrm{cm}^{-1}: 1595(\mathrm{C}=\mathrm{N})$, 1618 (aromatic ring stretch).

Compound 3m: ${ }^{1} \mathrm{H}$ NMR (200 MHz, $\left.\mathrm{CDCl}_{3}\right) \delta 2.49(\mathrm{~s}, 3 \mathrm{H})$, 7.29-7.40 (m, 5H), 7.45-7.52 (dd, $J=6 \mathrm{~Hz} \& 8 \mathrm{~Hz}, 2 \mathrm{H}), 7.64$ $(\mathrm{d}, J=8 \mathrm{~Hz}, 2 \mathrm{H}), 7.77-7.88$ (dd, $J=8 \mathrm{~Hz} \& 6 \mathrm{~Hz}, 3 \mathrm{H}), 8.06$ (d,
$J=8 \mathrm{~Hz}, 1 \mathrm{H}), 8.71$ (s, 1H, pyrazolyl-H) $\mathrm{ES}^{+} \mathrm{MS} m / z 368.15$ $\left(\mathrm{M}^{+}\right)$. IR $\left(\mathrm{KBr}\right.$ disc) $\mathrm{cm}^{-1}: 1590(\mathrm{C}=\mathrm{N}), 1621$ (aromatic ring stretch).

Compound 3n: ${ }^{1} \mathrm{H}$ NMR (200 MHz, DMSO- $\left.d_{6}\right) \delta$ 6.68-7.03 (dd, $J=8 \mathrm{~Hz}, 2 \mathrm{H}), 7.49-7.64(\mathrm{~m}, 4 \mathrm{H}), 7.95-8.24(\mathrm{~m}, 5 \mathrm{H})$ 8.34-8.41 (dd, $J=8 \mathrm{~Hz}, 2 \mathrm{H}), 8.78\left(\mathrm{~s}, 1 \mathrm{H}\right.$, pyrazolyl-H) $\mathrm{ES}^{+} \mathrm{MS}$ $m / z 399.44\left(\mathrm{M}^{+}\right)$. IR (KBr disc) $\mathrm{cm}^{-1}: 1370,1550,1595,(\mathrm{C}=\mathrm{N})$, 1616 (aromatic ring stretch).

Acknowledgments. The authors are thankful to Professor D. B. Ingle for his valuable discussion and directions during the work.

\section{References}

1. (a) Hutchinson, I.; Jennings, S. A.; Vishnuvajjala, B. R.; Westwell, A. D.; Stevens, M. F. G. J. Med. Chem. 2002, 45, 744. (b) Hutchinson, I.; Chua, M. S.; Browne, H. L.; Trapani, V.; Bradshaw, T. D.; Westwell, A. D.; Stevens, M. F. G. J. Med. Chem. 2001, 44, 1446.

2. (a) Chen, C.; Chen, Y. J. Tetrahedron Lett. 2004, 45, 113. (b) Tale, R. H. Org. Lett. 2002, 4, 1641. (c) Mathis, C. A.; Wang, Y. M.; Holt, D. P.; Huang, G. F.; Debnath, M. L.; Klunk, W. E. J. Med. Chem. 2003, 46, 2740. (d) Jackson, Y. A.; Lyon, M. A.; Townsend, N.; Bellabe, K.; Soltanik, F. J. Chem. Soc. Perkin Trans. 12000 , 205.

3. Das, J.; Moquin, R. V.; Liu, C.; Doweyko, A. M.; Defex, H. F.; Fang, Q.; Pang, S.; Pitt, S.; Shen, D. R.; Schieven, G. L.; Barrish, J. C. J. Bioorg. Med. Chem. Lett. 2003, 13, 2587.

4. Hays, S. J.; Rice, M. J.; Ortwine, D. F.; Johnson, G.; Schwarz, R. D.; Boyd, D. K.; Copeland, L. F.; Vartanian, M. G.; Boxer, P. A. J. Pharm. Sci. 1994, 83, 1425.

5. Foscolos, G.; Tsatsas, G.; Champagnac, A.; Pommier, M. Ann. Pharm. Fr. 1977, 35, 295.

6. Shirke, V. G.; Bobad, A. S.; Bhamaria, R. P.; Khadse, B. G.; Sengupta, S. R. Indian Drugs 1990, 27, 350.

7. Paget, C. J.; Kisner, K.; Stone, R. L.; Delong, D. C. J. Med. Chem. 1969, 12, 1016.

8. Gong, B.; Hong, F.; Kohm, C.; Bonham, L.; Klein, P. Bioorg. Med. Chem. Lett. 2004, 14, 1455.

9. Hutchinson, I.; Bradshaw, T. D.; Matthews, C. S.; Stevens, M. F. G.; Westwell, A. D. Bioorg. Med. Chem. Lett. 2003, 13, 471.

10. Ivanov, S. K.; Yuritsyn, V. S. Chem. Abstr. 1971, 74, 124487m.

11. (a) Chen, Y. X.; Qian, L. F.; Zhang, W.; Han, B. Angew. Chem. Int. Ed. 2008, 47, 9330. (b) Bahrami, K.; Khodaei, M. M.; Naali, F. J. Org. Chem. 2008, 17, 6835. (c) Chakraborti, A. K.; Rudrawar, S.; Jadhav, K. B.; Kaur, G.; Chankeshwara, S. V. Green Chem. 2007, 9, 1335. (d) Azarifar, D.; Maleki B.; Setayeshnazar M. Phosphorus, Sulfur Silicon Relat. Elem. 2009, 184, 2097. (e) Hein, D. W.; Alheim, R. J.; Leavitt, J. J. J. Am. Chem. Soc. 1957, 79, 427.

12. (a) Mourtas, S.; Gatos, D.; Barlos, K. Tetrahedron Lett. 2001, 42, 2201. (b) Njoya, Y.; Gellis, A.; Crozet, M.; Vanelle, P. Sulfur Lett. 2003, 26, 67. (c) Chakraborti, A. K.; Selvam, C.; Kaur, G.; Bhagat, S. Synlett 2004, 851. (d) Yildiz-Oren, I.; Yalcin, I.; Aki-Sener, E. Eur. J. Med. Chem. 2004, 39, 291. (e) Rudrawar, S.; Kondaskar, A.; Chakraborti, A. K. Synthesis 2005, 15, 2521.

13. (a) Laskar, I. R.; Chen, T. M. Chem. Mater. 2004, 16, 117. (b) Nadaf, R. N.; Siddiqui, S. A.; Daniel T.; Lahoti, R. J.; Srinivasan, K. V. J. Mol. Catal. A: Chem. 2004, 214, 155.

14. (a) Matsushita, H.; Lee, S. H.; Joung, M.; Clapham, B.; Janda, K. D. Tetrahedron Lett. 2004, 45, 313. (b) Chakraborti, A. K.; Selvam, C.; Kaur, G.; Bhagat, S. Synlett 2004, 851.

15. (a) Evindar, G.; Batey, R. A. J. Org. Chem. 2006, 71, 1802. (b) Itoh, T.; Mase, T. Org. Lett. 2007, 9, 3687. (c) Bose, S. D.; Idrees, M.; Srikanth, B. Synthesis 2007, 819. (d) Hutchinson, I.; Stevens, 
M. F. G.; Westwel, A. D. Tetrahedron Lett. 2000, 41, 425. (e) Mu, X. J.; Zou, J. P.; Zeng, R. S.; Wu, J. C. Tetrahedron Lett. 2005, 46, 4345.

16. Majo, V. J.; Prabhakaran, J.; Mann, J. J.; Kumar, J. S. D. Tetrahedron Lett. 2003, 44, 8535.

17. Pratap, U. R.; Mali, J. R.; Jawale, D. V.; Mane, R. A. Tetrahedron Lett. 2009, 50, 1352 and references cited therein.

18. Benjamin, G. D.; Viviane, B. Nat. Prod. Rep. 2001, 18, 618.

19. Wong, C. H.; Whitesides, G. M. Enzymes in Synthetic Organic Chemistry; Tetrahedron Organic Chemistry Series: 1994; Vol. 12, p 1.

20. Bommarius, A. S.; Riebel, B. R. Biocatalysis; Wiley-VCH Verlag GmbH \& Co.: 2004; Weinheim, p 1-15.

21. (a) Kumar, V.P.; Narender, M.; Sridhar, R.; Nageswar, Y. V. D.; Rama Rao, K. Syn. Commun. 2007, 37, 4331. (b) Surendra, K.;
Krishnaveni, N. S.; Sridhar, R.; Rama Rao, K. J. Org. Chem. 2006, 71, 5819. (c) Krishnaveni, N. S.; Surendra, K.; Reddy, M. A.; Nageswar, Y. V. D.; Rama Rao, K. J. Org. Chem. 2003, 68, 2018. (d) Narender, M.; Reddy, M. S.; Kumar, V. P.; Reddy, V. P.; Nageswar, Y. V. D.; Rama Rao, K. J. Org. Chem. 2007, 72, 1849. (e) Surendra, K.; Srilakshmi, K. N.; Mahesh, A.; Rama Rao, K. J. Org. Chem. 2006, 71, 2532. (f) Surendra, K.; Srilakshmi, K. N.; Nageswar, Y. V. D.; Rama Rao, K. J. Org. Chem. 2003, 68, 4994. (g) Madhav, B.; Narayana, M. S.; Reddy, V. P.; Rama Rao, K.; Nageswar, Y.V.D. Tetrahedron Lett. 2009, 50, 6025.

22. Breslow, R.; Steven, D. D. Chem. Rev. 1998, 98, 1997.

23. Bhosale, S. V. Mini. Rev. Org. Chem. 2007, 4, 3.

24. Szejtli, J.; Osa, T. Comprehensive Supramolecular Chemistry; Vol. 3, Pergamon: 1996; New York. 